\title{
KÖZLEMÉNY
}

\section{A magyarországi németek disszimilációjának területi jellemzői}

\author{
Tóth Ágnes - Vékás János
}

\section{ÖSSZEFOGLALÓ}

A szerzők a 2001. és 2011. évi magyarországi népszámlálások adatainak összehasonlításával kiszámították, hogy a német nemzeti kisebbséghez kötődő személyek létszám-növekedése kistérségenként minimálisan milyen mértékben ered a disszimilációból. Német kötődésűeknek azokat tekintették, akik a népszámlálás nemzeti-etnikai kötődésre vonatkozó kérdéscsoportjának legalább egy kérdése esetében a németet jelölték meg. Disszimilánsoknak azokat a 2011. évi népszámláláskor magukat német kötődésűeknek vallókat tekintették, akik a 2001. évi népszámlálás során még egyetlen népszámlálási kérdés tekintetében sem vallották magukat a németséghez kötődőnek. A migráció hatásának kiszürése érdekében vizsgálatukat csak a születésük óta azonos lakcímen lakó német kötődésűekre korlátozták, és az egyes születési évjáratok létszámának összehasonlításával végezték. Az eredmények szerint a disszimiláció minimális mértékének kistérségi mutatója nagy szórást mutat, de nem áll szoros korrelációban sem a kistérség, sem az általa lakott német kötődésűek alapvető mutatóival. A szerzők a kapott kistérségi disszimilációs mutatók alapján látják célszerünek kijelölni azokat a terepeket, amelyeken további részletes társadalomszerkezeti és társadalomtörténeti vizsgálatokkal tárhatók fel a disszimilációval kapcsolatos oksági összefüggések.

Tárgyszavak: németek, népszámlálás, identitás, disszimiláció

Tóth Ágnes

MTA TK Kisebbségkutató Intézet

E-mail: toth.agnes@tk.mta.hu
Vékás János

MTA TK Kisebbségkutató Intézet

E-mail:vekas.janos@tk.mta.hu 


\section{BEVEZETÉS}

Korábbi elemzéseinkben (Tóth - Vékás 2013, 2014a, 2014b, 2016) kimutattuk, hogy egyes magyarországi nemzeti kisebbségek esetében a 2001. és 2011. évi népszámlálás közötti időszakban bekövetkezett jelentős létszámnövekedés jórészt a disszimilációból ered, vagyis abból, hogy a 2011. évi népszámlálás során olyanok is egy adott kisebbséghez kötődőnek vallották magukat, akik 2001-ben még nem így nyilatkoztak.

A disszimiláció mértéke különösen a németség körében mutatkozott magas arányúnak a létszámot befolyásoló két másik tényező, a természetes szaporodás (az élveszületések és a halálozások különbözete) és a vándorlási különbözet (az odavándorlók és elvándorlók számának különbözete) befolyási arányához képest.

Ez a tény sok mindent elmondhat a társadalmi szerkezet mélyrétegeiben zajló folyamatokról, de csak akkor, ha fényt derítünk a jelenség okaira, tehát mindenek előtt kimutatjuk, milyen körülmények közepette, milyen mértékben és módon jelentkezik.

Ennek érdekében valamelyest finomítottunk a disszimilációval kapcsolatos eddigi kutatásaink módszertanán. A disszimiláció minimális mértékét eddig úgy számítottuk ki, hogy kisebbségenként megvizsgáltuk, a születésük óta azonos lakcímen lakók száma ötéves korcsoportonként hogyan változott meg a két népszámlálás (2001 és 2011) között. Tehát, például a Pilisvörösváron 2001-ben összeírt 5-9 évesek (akik 2011-re 15-19 évesek lettek) száma hogyan viszonyul a 2011ben összeírt 15-19 évesek számához. A jelenség szignalizálásához ez az eljárás elégséges volt, de a pontosabb elemzés érdekében azt is figyelembe kell venni, hogy a két népszámlálás 2001. február 1-jei és 2011. október 1-jei eszmei időpontja között nem pontosan tíz év, hanem ennél hét hónappal több idő telt el, ami bizonyos mértékben torzította az eredményeket. Ezt a korlátozást úgy iktattuk ki, hogy egyrészt nem a korévet, hanem a születési évet vettük alapul, másrészt nem öt, hanem egyéves időszakokra számítottuk ki a disszimiláció minimális mértékét.

\section{A 2001. ÉS A 2011. ÉVI NÉPSZÁMLÁLÁS ETNODEMOGRÁFIAI ADATAI ÖSSZEHASONLÍTHATÓSÁ- GÁNAK LEHETÖSÉGEI ÉS KORLÁTAI}

A 2001. és a 2011. évi népszámlálás nemzeti-etnikai identitásra vonatkozó kérdései között a következő az eltérés: míg 2001-ben a témára vonatkozó négy népszámlálási kérdésre (milyen nemzetiségű; mi az anyanyelve; családi, baráti 
közösségben mely nyelvet használja; mely nemzet kultúrájához kötődik) 3-3 választ lehetett adni, addig 2011-ben már kimaradt a kulturális kötődésre vonatkozó kérdés, a megmaradt kérdésekre pedig 2-2 választ adhattak, a nemzetiségre vonatkozó válaszlehetőségeket ugyanis ketté bontották.

E módszertani eltérések miatt felmerült a kérdés, össze lehet-e hasonlítani „az almát a körtével”. Akik az összehasonlítás lehetősége ellen érvelnek, a kisebbségi identitásdeklarációk számának 2011. évi jelentős arányú növekedését e módszertani különbségekkel magyarázzák (pl. Morauszki - Papp Z. 2014: 98; Kapitány 2015: 99-100), illetve a módszertani összehasonlítás szempontjából is a 2011-es magas nem válaszolási arányt jelölik meg az egyik legfontosabb tényezőként (Kapitány 2013: 32-36).

Mi vezethetett volna a növekedéshez e módszertani eltérések közül?

1. A kulturális kötődés kérdésének elhagyásától - értelemszerủen - semmiképpen sem növekedhetett az adott kisebbséghez kötődők száma. Bár rendkívül eltérő mértékben, de minden kisebbség esetében a hozzájuk kötődők egy része kizárólag a kulturális kötődés megjelölésével került az adott kisebbség körébe. Egy részük 2011-ben - amikor e kérdés már nem szerepelt a népszámlálási kérdőíven - már nyilvánvalóan a nemzetiség, az anyanyelv vagy a családi nyelv keretében jelezte az adott kisebbséghez való kötődését, de azt is feltételeznünk kell, hogy a másik részük viszont kikerült az adott kisebbséghez való kötődést jelzők köréből.

2. Magától értetődő, hogy a lehetséges válaszok számának 3-ról 2-re csökkentéséből kifolyólag sem feltételezhetjük az identitásdeklarációk számának növekedését, még ha tudjuk is, hogy az egy-egy kérdésre 3 választ adók száma a statisztikai makroelemzés szempontjából rendkivül csekély.

3. Fennáll még az a lehetőség, hogy az identitásdeklarációk számának növekedését a nemzetiségre vonatkozó két lehetséges válasz két kérdésre bontása (,Mely nemzetiséghez tartozónak érzi magát?”; ,Az előző kérdésnél megjelöltön kívül tartozik-e másik nemzetiséghez is?") idézte elő.

Az adatok összehasonlítása alapján első pillantásra úgy tünik, hogy ez az érvelés indokolt. Ha például megvizsgáljuk a német nemzetiségüeket, akkor látjuk, hogy míg 2001-ben több mint felük jelölt meg csak egy nemzetiséget, addig 2011-ben arányuk alig haladta meg a 20\%-ot (1. táblázat). Eközben a lehetséges három válasz közül több mint háromnegyedük a németet és a magyart jelölte meg. 
1. táblázat: A német kötődésüek megoszlása a nemzetiség kérdésére adott válaszok alapján Distribution of people with German ties based on responses to the question on ethnicity

\begin{tabular}{lcccc} 
Nemzetiség & $\begin{array}{c}\text { 2001. év, } \\
\text { fő }\end{array}$ & $\begin{array}{c}\text { 2011. év, } \\
\text { fő }\end{array}$ & $\begin{array}{c}\text { 2001. év, } \\
\%\end{array}$ & $\begin{array}{c}\text { 2011. év, } \\
\%\end{array}$ \\
\hline Csak német & 32746 & 27930 & 52,7 & 21,2 \\
Német és magyar & 29198 & 102349 & 47,0 & 77,6 \\
Német és más & 161 & 1672 & 0,3 & 1,3 \\
Összesen & 62105 & 131951 & 100,0 & 100,0
\end{tabular}

Forrás: KSH, 2001. és 2011. évi népszámlálások elektronikus adatbázisa.

Ha azonban ezeket az arányokat az anyanyelv kérdésének vonatkozásában vizsgáljuk meg (2. táblázat), akkor azt állapíthatjuk meg, hogy jóval nagyobb arányban nőtt a két választ adók aránya, holott e kérdés esetében a kérdezetteket nem ösztönözték erre két külön kérdés feltevésével, mint ahogy a nemzetiség esetében tették.

2. táblázat: A német kötődésüek megoszlása az anyanyelv kérdésére adott válaszok alapján Distribution of people with German ties based on responses to the question on native language

$\begin{array}{lcccc}\text { Anyanyelv } & \begin{array}{c}\text { 2001. év, } \\ \text { fö }\end{array} & \begin{array}{c}\text { 2011. év, } \\ \text { fő }\end{array} & \begin{array}{c}\text { 2001. év, } \\ \%\end{array} & \begin{array}{c}\text { 2011. év, } \\ \%\end{array} \\ \text { Csak német } & 24933 & 17667 & 73,8 & 46,2 \\ \text { Német és magyar } & 8800 & 20260 & 26,1 & 53,0 \\ \text { Német és más } & 41 & 321 & 0,1 & 0,8 \\ \text { Összesen } & 33774 & 38248 & 100,0 & 100,0\end{array}$

Forrás: KSH, 2001. és 2011. évi népszámlálások elektronikus adatbázisa.

Ugyanígy növekedett a többes kötődést jelölők aránya a családi, baráti közösségben beszélt nyelv (a továbbiakban az ábrákon és a táblázatokban röviditve: családi nyelv) esetében is, bár itt már 2001-ben is rendkivül csekély volt azok száma, akik a családban csak németül beszéltek (3. táblázat). 
3. táblázat: A német kötődésüek megoszlása a családi, baráti közösségben beszélt nyelv kérdésére adott válaszok alapján

Distribution of people with German ties based on responses to the question on the language spoken in the family and among friends

\begin{tabular}{lcccc}
\hline Családi nyelv & $\begin{array}{c}\text { 2001. év, } \\
\text { fő }\end{array}$ & $\begin{array}{c}\text { 2011. év, } \\
\text { fő }\end{array}$ & $\begin{array}{c}\text { 2001. év, } \\
\%\end{array}$ & $\begin{array}{c}\text { 2011. év, } \\
\%\end{array}$ \\
\hline Csak német & 7520 & 8094 & 14,2 & 8,5 \\
Német és magyar & 45185 & 86028 & 85,4 & 89,9 \\
Német és más & 207 & 1539 & 0,4 & 1,6 \\
Összesen & 52912 & 95661 & 100,0 & 100,0
\end{tabular}

Forrás: KSH, 2001. és 2011. évi népszámlálások elektronikus adatbázisa.

A válaszmegtagadók számának 2001 és 2011 közötti nagyarányú növekedését illetően az általunk ismert etnodemográfiai elemzések egyike sem tartalmazza annak a hatásmechanizmusnak a leírását, amely révén a válaszmegtagadók számának növekedése összefüggésbe hozható lenne a kisebbségi identitásdeklarációk számának növekedésével.

Mindez azt bizonyítja, hogy a 2001. és 2011. évi népszámlálások közötti módszertani eltérések nem befolyásolták lényegesen az eredményeket. A változások a „valós társadalmi folyamatokat” tükrözik, természetesen nemcsak azokat, amelyek a kisebbségek keretében zajlottak, hanem azokat is, amelyek a környezetükben játszódtak le, mi több, e két tényezőcsoport folyamatos interaktív viszonyban áll egymással. Ezzel a kérdéssel azonban egy korábbi tanulmányunkban részletesen foglalkoztunk (Tóth - Vékás 2008).

\section{ORSZÁGOS ÉRTÉKEK}

Mint ismeretes, a 2001. évi népszámlálás' során 120344 fő, 2011-ben pedig 185695 fő vallotta magát legalább egy kérdés kapcsán a németséghez kötődőnek, ami 154\%-os növekedés. Születési évenkénti bontásban azonban ez a különbség egyes évjáratokban még ennél is lényegesen nagyobb. A 2011. évi népszámlálás során csak az 1936 előtt születettek körében írtak össze kevesebb német kötődésüt, mint 2001-ben.

\footnotetext{
${ }^{1}$ Az elemzésünkben feltüntetett népszámlálási adatok a Központi Statisztikai Hivatal elektronikus adatbázisából származnak. Ugyanez a forrása az összes táblázatnak és ábrának is.
} 
Ugyanakkor, miközben a 2001. évi népszámláláson a 2000-ben született csecsemők közül még csak 246-ot deklaráltak német kötődésűnek a szüleik, 2011-ben az akkor tíz éves német kötődésűek száma már 1337 fő volt, vagyis 10 év alatt öt és félszeresére (544\%) nőtt. Ezt követően nagyjából egyenletesen mérséklődik a növekedési arány egészen az 1984-ben születettekig, hiszen az életkorral együtt növekszik a halálesetek száma, akárcsak az elvándorlásoké, s e tényezők hatása már nagyobb mértékben ellensúlyozza a disszimiláció hatását.

Külön vizsgálatot igényel az 1973 és 1976 között született „Ratkó-unokák”2 körében tapasztalható magas disszimilációs arány (az 1975-ben született német kötődésűek száma 2011-ben a 2001. évi érték 218,9\%-a).

A disszimiláció létszám-növekedésre gyakorolt hatásának ez a minimális mértéke, mert nem ismeretes előttünk, hogy a két népszámlálás között a német kötődésüek mekkora hányada halt meg, illetve vándorolt el, amit ugyancsak a disszimilációnak kellett ellentételeznie.

\section{A külső vándorlás hatása}

Az évenkénti országos születési létszám-növekedés értékeire a disszimiláció mellett még a bevándorlás is lényeges hatást gyakorolhatott. Ezért ahhoz, hogy megállapítsuk a disszimiláció létszámnövelő hatásának országos értékét, ki kellett zárnunk a bevándorlás hatását, azaz elemzésünket a Magyarországon született német kötődésủekre korlátoztuk.

Bár a külföldön született német kötődésűek száma a két népszámlálás közötti időszakban majdnem a kétszeresére nőtt, arányuk a németségen belül alig több mint egy százalékkal lett magasabb. Semmiképp sem lehetett tehát a magyarországi németség markáns létszám-növekedésének meghatározó tényezője. A korrekt elemzés érdekében azonban mégis vessünk egy pillantást hatásának jellegére és mértékére.

Az 1. ábrán láthatjuk, hogy a külföldön születettek nem azoknál a születési éveknél gyarapítják a magyarországi németség létszámát, amelyeknél 2001 és 2011 között a legnagyobb volt a növekedés. 2001-ben csak az 1918-ban és korábban születettek körében haladta meg a külföldön születettek aránya a 10\%-ot, 2011-ben pedig csak az 1941 és 1945 között születettek (akkor 66-70 évesek) körében érte el a 20\%-ot.

${ }^{2} 1953$ februárjában a kormányzat minisztertanácsi rendelettel betiltotta az abortuszt, illetve bevezette a gyermektelenségi adót és a gyermekvállalási kedvezményeket. A következő években 15\%-kal nőtt a születések száma. Az időszakot Ratkó Anna egészségügyi miniszterről „Ratkó-korszak”-nak, az akkor születetteket „Ratkó-gyerekek”-nek nevezték el (Pongrácz 2013). 
1. ábra: Az összes és a Magyarországon született német kötődésủek országos létszámának születési év szerinti száma, 2001-2011 (fö)

The number of all people with German ties and of those born in Hungary by year of birth. 2001-2011 (persons)

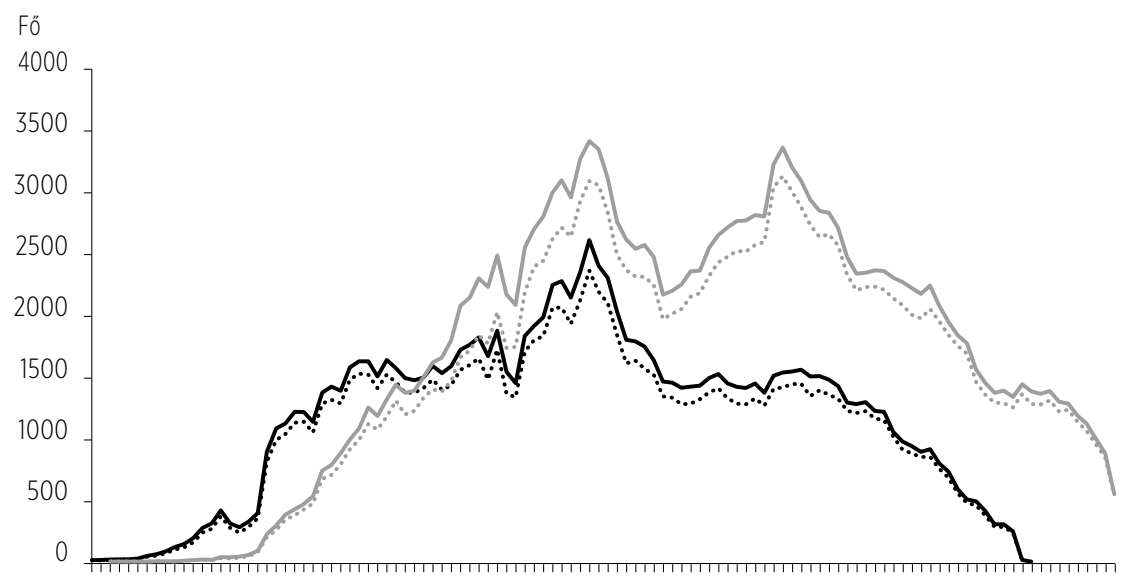

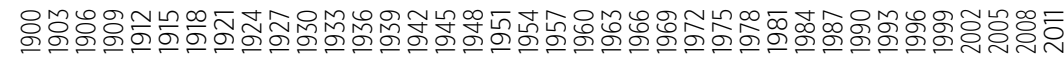

— Összes, 2001

— Összes, 2011
....... Magyarországon született, 2001

........ Magyarországon született, 2011

Forrás: KSH, 2001. és 2011. évi népszámlálások elektronikus adatbázisa.

Összegezve: a német kötődésűek száma Magyarországon a 2001-ben öszszeírt 120344 föről 2011-ig 185696 före gyarapodott, a többlet tehát 65352 fő. Ebből a külföldön születettek gyarapodása 7744 fő (a 2001. évi 9756 főről a 2011. évi 17500 före). Hátramarad tehát a Magyarországon születettek 57 608 fős (a 2001. évi 110588 főről a 2011. évi 168196 főre) gyarapodásának magyarázata.

Ezt úgy oldjuk meg, hogy táblázatunkban egymás mellé rendeljük az adott évben születettek 2001., illetve 2011. évben összeírt számát, és kiszámoljuk a két érték soronkénti különbségét (4. táblázat).

Ahogy a 4. táblázatból is láthatjuk, az 1900 és 1938 közötti évjáratok mindegyikében fogyás jelentkezett. Ezen sorokban a Különbség-oszlop mezőinek értékeit összeadva megállapíthatjuk, hogy a 2001-ben 63-101 évesek létszáma 2011-ben 10986 fővel lett kevesebb. 
4. táblázat: A Magyarországon született német kötődésüek születési évjáratonkénti létszámkülönbsége, 2001-2011

Change in the number of people with German ties born in Hungary by birth year, 2001-2011

\begin{tabular}{|c|c|c|c|}
\hline Születési év & $\begin{array}{l}\text { Német, } \\
2001\end{array}$ & $\begin{array}{l}\text { Német, } \\
2011\end{array}$ & Különbség \\
\hline 1900 & 12 & & -12 \\
\hline 1901 & 10 & & -10 \\
\hline 1902 & 14 & 1 & -13 \\
\hline 1903 & 16 & 1 & -15 \\
\hline 1904 & 18 & 1 & -17 \\
\hline 1932 & 1518 & $\begin{array}{ll}\cdots & \\
& 1178\end{array}$ & -340 \\
\hline 1933 & 1456 & 1307 & -149 \\
\hline 1934 & 1372 & 1195 & -177 \\
\hline 1935 & 1371 & 1225 & -146 \\
\hline 1936 & 1410 & 1332 & -78 \\
\hline 1937 & 1479 & 1399 & -80 \\
\hline 1938 & 1395 & 1383 & -12 \\
\hline 1939 & 1432 & 1468 & 36 \\
\hline 1940 & 1558 & 1662 & 104 \\
\hline 1941 & 1596 & 1712 & 116 \\
\hline 1942 & 1651 & 1838 & 187 \\
\hline 1943 & 1478 & 1771 & 293 \\
\hline 1944 & 1722 & 2025 & 303 \\
\hline 1945 & 1363 & 1735 & 372 \\
\hline 1946 & 1336 & 1744 & 408 \\
\hline 1998 & 283 & 1291 & 1008 \\
\hline 1999 & 281 & 1287 & 1006 \\
\hline 2000 & 236 & 1251 & 1015 \\
\hline 2001 & 14 & 1359 & 1345 \\
\hline 2002 & & 1280 & 1280 \\
\hline 2003 & & 1277 & 1277 \\
\hline 2004 & & 1310 & 1310 \\
\hline 2005 & & 1219 & 1219 \\
\hline 2006 & & 1233 & 1233 \\
\hline 2007 & & 1137 & 1137 \\
\hline 2008 & & 1062 & 1062 \\
\hline 2009 & & 952 & 952 \\
\hline 2010 & & 848 & 848 \\
\hline 2011 & & 538 & 538 \\
\hline Összesen & 110588 & 168196 & 57608 \\
\hline
\end{tabular}

Forrás: KSH, 2001. és 2011. évi népszámlálások elektronikus adatbázisa. 
Az 1939 és 2000 között születettek minden évjáratában viszont többlet jelentkezett: a 2001-ben 1-62 évesek létszáma 2011-re 56393 fővel lett több. Emellett a 2011. évi népszámláláskor 12 201, 2001 és 2011 között született német kötődésüt írtak össze.

Mindez tehát azt jelenti, hogy a Magyarországon született német kötődésủek 2001 és 2011 közötti 57608 fős növekményének 21,2\%-a a születésekből, 78,8\%-a pedig az évjáratonkénti többlet, illetve fogyás különbözetéből ered (5. táblázat).

5. táblázat: A Magyarországon született német kötődésủek 2001 és 2011 közötti disszimilációs növekményének minimuma

The minimal dissimilation increment (between 2001 and 2011) of people with German ties born in Hungary

\begin{tabular}{lccc} 
& $\begin{array}{c}\text { Különbözet, } \\
\text { fö }\end{array}$ & $\begin{array}{c}\text { A 2001-2011. évi } \\
\text { növekményből, } \\
\%\end{array}$ & $\begin{array}{c}\text { A 2011. évi } \\
\text { összlétszámból, } \\
\%\end{array}$ \\
\hline $\begin{array}{l}\text { Fogyás sorok összege }= \\
\text { a halálozás+elvándorlás+ } \\
\text { asszimiláció minimuma }\end{array}$ & & & \\
Többlet sorok összege $=$ & -10986 & & 33,5 \\
$\quad$ a disszimilánsok számának minimuma & 56393 & & 7,3 \\
Születések 2001 és 2011 között & 12201 & 21,2 & \\
2011-2001 különbözet összesen & 57608 & & \\
Többlet és Fogyás különbözete & 45407 & 78,8 &
\end{tabular}

Forrás: KSH, 2001. és 2011. évi népszámlálások elektronikus adatbázisa.

Ugyanakkor azt is megállapithatjuk, hogy a pozitív különbözetű évjáratok többletének összege (56 393 fő) képezte 2011-ben a Magyarországon született német kötődésủek összlétszámának 33,5\%-át. Ők alkotják a disszimilánsok létszámának minimumát, amit a következő okokból nevezünk minimumnak.

Egyrészt, az elvándorlás és visszavándorlás különbözete esetében nincs népszámlálási adatunk arról, hogy a 2001. évi népszámlálás időpontjában hány Magyarországon született személy tartózkodott külföldön azok közül, akiket 2011-ben már ismét magyarországi lakhelyükön írtak össze, és fordítva, mennyien távoztak külföldre. (Közbevetőleg jegyezzük meg: nemcsak etnodemográfiai kutatásaink számára, hanem sok más célból is nagyon hasznos lenne egy olyan népszámlálási kérdés, amely azt tudakolná, hogy a kérdezettet hol írták össze az előző népszámlálás során.) 
Másrészt, a születések és halálozások különbözete esetében a születési év alapján pontosan tudjuk ugyan a születések számát, de az elhalálozottak száma a népszámlálási forrásokból nem ismerhető meg.

Harmadrészt, az asszimiláció és disszimiláció különbözete esetében az asszimiláció mértékéről is csak feltételezésekbe bocsátkozhatunk.

Mindezen okok oda vezetnek, hogy azoknak a személyeknek a száma, akiket 2011-ben németként írtak össze, de a 2001. évi népszámláláskor még nem mondták magukat németnek, semmiképpen sem lehetett kisebb a feltüntetett értéknél, nagyobb azonban lehetett, mert az elhunytak, elvándoroltak vagy aszszimilálódottak létszámát is csak a disszimilánsok pótolhatták. Elemzésünk célja azonban nem ezeknek a kérdéseknek a taglalása, hanem alapvetően arról igyekszünk minél többet megtudni, hogy a magyarországi németség körében tapasztalható disszimiláció hátterében milyen tényezők feltételezhetők, hipotéziseket alkotva a további kutatásokhoz. Ezért az oksági összefüggések feltárásának előkészitése céljából megvizsgáljuk, hogy különböző helyeken és körülmények között milyen mértékben jut kifejezésre, illetve a társadalmi szerkezet egyéb mutatóival hol milyen mértékben korrelál. Ennek első lépése a disszimiláció területi jellemzőinek vizsgálata.

\section{A belső vándorlás hatása}

A disszimiláció területi jellemzőinek vizsgálatához a külső vándorlás mellett a belső vándorlás létszámváltozásra gyakorolt lehetséges hatását is ki kell zárni. Erre az a népszámlálási adat nyújt lehetőséget, amely megjelöli azon kérdezetteket, akik születésük óta azonos lakcímen laknak.

Ezen személyek a vizsgált népességcsoportnak, esetünkben a magyarországi németségnek csak egy kisebb részét képezik, amely emellett még sajátos demográfiai jellemzőkkel is rendelkezik. A vizsgálatuk által kapott eredmények semmiképpen sem vonatkoztathatók mechanikusan a magyarországi németség egészére, de létszámuk még megbízható alapot nyújt a statisztikai elemzésre.

A 2001. évi népszámlálás során a 120344 német kötődésủ közül 19351 olyan személyt írtak össze, aki születése óta azonos lakcímen lakott. Ők akkor a német kötődésủek 16,1\%-át képezték. 2011-re a német kötődésűek száma 185 696-ra 
nőtt (a 2001. évi érték 154,3\%-a), miközben ez utóbbiak közül 33108 fő nem költözött (a 2001. évi érték 171,1\%-a), így részesedésük a német kötődésúek körében már 17,8\%-ot tett ki.

Vizsgáljuk meg a következőkben a nem költözött német kötődésủek évjáratonkénti disszimilációs jellemzőit (2. ábra).

2. ábra: A születésük óta azonos lakcímen lakó német kötődésüek országos létszámának születési év szerinti megoszlása, 2001-2011 (fö)

The number of people with German ties who have resided at the same place since birth by year of birth, 2001-2011 (persons)

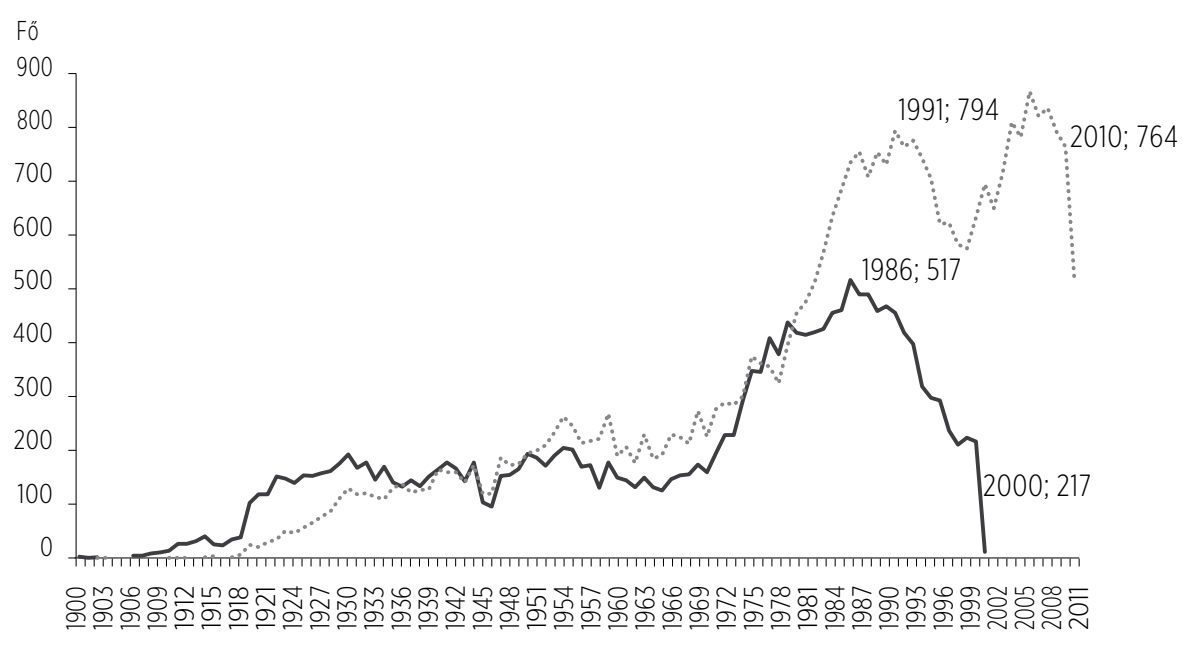

- $2001 \quad$-.......2011

Forrás: KSH, 2001. és 2011. évi népszámlálások elektronikus adatbázisa.

Esetükben az 1945-ös évjáratnál fordul többletbe a létszámkülönbözet, s az e sorok összegét kitevő 7284 fő képezi a disszimilánsok számának minimumát. Ha ebből kivonjuk az 1900-1944-es évjáratok fogyását, az 5520 fő képezi a 2001 és 2011 közötti növekmény születéseken felüli részét. Miután a 2001 és 2011 között született német kötődésủek a születésük óta azonos lakcímen lakók gyarapodásának 59,9\%-át képezik, a növekményből a disszimilánsokra 40,1\% esik (6. táblázat). 
6. táblázat: A születésük óta azonos lakcímen lakó német kötődésüek 2001-2011 közötti disszimilációs növekményének minimuma

The minimal dissimilation increment (between 2001 and 2011) of people with German ties who have resided at the same place since birth

\begin{tabular}{|c|c|c|c|}
\hline & $\begin{array}{l}\text { Különbözet, } \\
\text { fő }\end{array}$ & $\begin{array}{c}\text { A 2001-2011. évi } \\
\text { növekményből, } \\
\%\end{array}$ & $\begin{array}{c}\text { A 2011. évi } \\
\text { összlétszámból, } \\
\%\end{array}$ \\
\hline \multicolumn{4}{|l|}{$\begin{array}{l}\text { Fogyás sorok összege = } \\
\text { a halálozás+elvándorlás+ }\end{array}$} \\
\hline asszimiláció minimuma & -1765 & & \\
\hline $\begin{array}{l}\text { Többlet sorok összege = } \\
\text { a disszimilánsok számának minimuma }\end{array}$ & 7285 & & 22,0 \\
\hline Születések 2001 és 2011 között & 8237 & 59,9 & 24,9 \\
\hline 2011-2001 különbözet összesen & 13757 & & \\
\hline Többlet és Fogyás különbözete & 5520 & 40,1 & \\
\hline
\end{tabular}

Forrás: KSH, 2001. és 2011. évi népszámlálások elektronikus adatbázisa.

Megfigyelhetjük, hogy míg a Magyarországon született német kötődésűek 2011. évi összlétszámából a 2001. és 2011. év közötti születések 7,3\%-kal részesedtek, addig a születésük óta azonos lakcímen lakók esetében arányuk 24,9\%-ot tesz ki. Az eltérés abból ered, hogy a születésük óta azonos lakcímen lakó német kötődésűek korösszetétele sokkal fiatalabb, mint a német kötődésűek összlétszámáé, mivel minél fiatalabb az illető, annál kevesebb körülmény ösztönzi vagy kényszeríti a vándorlásra. Ugyanakkor a korösszetételből eredő különbségek megfelelő módszertani megkötések figyelembe vételére köteleznek bennünket, amelyekre Az extrapolálás kockázatai című részben térünk ki részletesen.

\section{TERÜLETI KÜLÖNBSÉGEK}

Ha azt akarjuk kideríteni, hogy a területi különbségek hogyan befolyásolják a német közösség disszimilációs jellemzőit, azt kell szem előtt tartanunk, hogy a túl nagy területi egység (megye) átlagai elfedik a különbségeket, a túl kis egység (település) csekély esetszámai pedig alkalmatlanok a statisztikai elemzésre. 
Ezen megfontolásokból döntöttünk a kistérségi beosztás mellett, amely a 2001. évi népszámlálás időpontjában 150 egységre osztotta fel Magyarország területét, és ezekre számítottuk át a 2011. évi népszámlálás adatait is.

A 150 kistérség mindegyikében írtak össze német kötődésüt 2001-ben és 2011-ben is, akiknek egy része születése óta azonos lakcímen lakott.

A születésük óta azonos lakcímen lakó német kötődésüek létszámának alakulásában a disszimiláció szerepe kistérségenként rendkívül eltérő volt. A Hajdú-Bihar megyében lévő Balmazújvárosi kistérségben például a 2011-ben összeírt 30 olyan német kötődésủből, aki születése óta azonos lakcímen lakott, 2001-ben még csak egyetlen ilyen személyt írtak össze. Miután 2001 és 2011 között csak két olyan gyermek született, aki e kategóriába sorolható, a további 27 fős növekmény a disszimiláció minimális mértékét mutatja (90\%). A másik szélsőség a Mohácsi kistérség, ahol a legutóbbi két népszámlálás között a német kötődésűek létszáma annak ellenére is csökkent, hogy 2001-ben a kistérségben az összlakosság majdnem egyötödét tették ki (19,9\%). Azonban még itt is volt valamennyi disszimiláció, amelynek minimális mértéke számításunk szerint a születésük óta azonos lakcímen lakók 2011. évi létszámának 5,4\%-át képezte.

Vizsgáljuk meg először példaként a disszimiláció minimális mértékének szélsőséges értékeit mutató két kistérség németségének jellemzőit (Balmazújvárosban 90\%; Mohácson 5,4\%), hogy közelebb kerüljünk a disszimiláció jelenségének megértéséhez.

\section{Balmazújvárosi kistérség: az erőteljes revitalizáció példája}

2001-ben a Hajdú-Bihar megyei, 30256 lakosú Balmazújvárosi kistérségben 27 személy mondta magát német kötődésűnek a népszámlálás legalább egy kérdése kapcsán. Közülük csak egy élt 1961-es születése óta az akkori lakóhelyén, a kistérség központját képező Balmazújvárosban. Nemzetisége és kulturális kötődése szerint vallotta magát németnek. Beszélte a német nyelvet, bár az nem volt anyanyelve, és családi, baráti környezetben se használta.

2011-re a német kötődésủek száma 209 főre nőtt (774\%). Még nagyobb arányú volt a születésük óta azonos lakcímen lakók növekedése (30 fő, tehát a 2001. évi érték 3000\%-a), közülük ketten születtek a két legutóbbi népszámlálás közötti időszakban.

A német identitásukat újonnan deklarálók a 2011. évi népszámlálás időpontjában elenyésző kivétellel 17-35 évesek voltak. 


\section{A disszimilánsok számának minimuma}

A születési évjáratok - az ismertetett módszerrel való - összevetése során megállapíthatjuk, hogy a születésük óta azonos lakcímen lakók 29 fős növekményéhez 6,9\%-ban járultak hozzá a születések, 93,1\%-ban pedig a disszimiláció, továbbá hogy a kistérségben legalább 27 olyan német kötődésüt írtak össze, aki már a 2001. évi népszámláláskor is jelen volt, de akkor még nem vallotta magát németnek. A 30 fős összlétszámból tehát 90\% jut a disszimilánsokra, 6,7\% a 2001. évi népszámlálás után születettekre, és a maradék 3,3\% azokra, akik már a 2001. évi népszámlálás során is németnek vallották magukat.

\section{A válaszkombinációk}

A válaszkombinációk összehasonlításából látjuk, hogy azok aránya nőtt a legnagyobb mértékben, akik kizárólag nemzetiségük deklarálásával kötődtek a németséghez (1. számú válaszkombináció; 7. táblázat).

7. táblázat: A német kötődésủek válaszkombinációinak összehasonlitása, Balmazújvárosi kistérség, 2001,2011

Comparison of response combinations of people with German ties, Balmazújváros Subregion, 2001, 2011

\begin{tabular}{|c|c|c|c|c|c|c|c|c|}
\hline \multirow{2}{*}{$\begin{array}{l}\text { Válasz- } \\
\text { komb. }\end{array}$} & \multicolumn{3}{|c|}{ Identitáskategória } & \multicolumn{2}{|c|}{2001} & \multicolumn{2}{|c|}{2011} & \multirow{2}{*}{$\begin{array}{c}2011 / 2001 \\
\%\end{array}$} \\
\hline & nemz & anye & csbeny & fö & $\%$ & fö & $\%$ & \\
\hline 01 & $x$ & - & - & 6 & 28,6 & 133 & 63,6 & 35,1 \\
\hline 03 & - & $x$ & - & 1 & 4,8 & 2 & 1,0 & $-3,8$ \\
\hline 04 & - & - & $x$ & 7 & 33,3 & 56 & 26,8 & $-6,5$ \\
\hline 07 & $x$ & $x$ & - & 2 & 9,5 & 1 & 0,5 & $-9,0$ \\
\hline 08 & $x$ & - & $x$ & 0 & 0,0 & 3 & 1,4 & 1,4 \\
\hline 10 & $x$ & $x$ & $x$ & 5 & 23,8 & 14 & 6,7 & $-17,1$ \\
\hline 19 & - & $x$ & $x$ & 0 & 0,0 & & 0,0 & 0,0 \\
\hline \multicolumn{3}{|l|}{ Összesen } & & 21 & 100 & 209 & 100 & \\
\hline \multicolumn{3}{|c|}{ Csak kulturális kötődés } & & 6 & & & & \\
\hline \multicolumn{2}{|l|}{ Együtt } & & & 27 & & 209 & & \\
\hline
\end{tabular}

Forrás: KSH, 2001. és 2011. évi népszámlálások elektronikus adatbázisa.

Megjegyzés: Az X-szel jelölt identitáskategóriák azt jelölik, hogy az adott sorban összeszámolt személyek mely népszámlálási kérdések (nemzetiség; anyanyelv; családi, baráti közösségben beszélt nyelv) szerint mondták magukat a németséghez kötődőnek. Miután a 2011. évi népszámlálás - a 2001. évivel ellentétben - nem kérdezett rá a kulturális kötődésre, mindazok számát, akik 2001-ben kizárólag ennek kapcsán jelezték a németséghez való kötődésüket, külön sorban tüntettük fel, de értelemszerüen nem vontuk be az összehasonlításba. 


\section{Az identitáskategóriák}

A nemzetiségi identitásdeklarációk növekedése megmutatkozik az identitáskategóriák arányaiban is. A 8. táblázatból látjuk, hogy 2011-re a nemzetiségük szerint a németséghez kötődők száma a 2001. évi létszám több mint tízszeresére nőtt, de meghatszorozódott a családban német nyelvet használók száma is. A német anyanyelvűek száma nőtt a legkisebb mértékben az identitáskategóriák közül. Az aktív (nemzetiség) és passzív (anyanyelv és családi nyelv) identitáskategóriák növekedési aránya a német kötődésűek további revitalizációjának előjele.

8. táblázat: A német kötődésüek által jelölt identitáskategóriák, Balmazújvárosi kistérség, 2001, 2011 Identity categories indicated by people with German ties, Balmazújváros Subregion, 2001, 2011

\begin{tabular}{lccc} 
Év & Nemzetiség & Anyanyelv & Családi nyelv \\
\hline 2001 & 13 & 8 & 12 \\
2011 & 151 & 17 & 73
\end{tabular}

Forrás: KSH, 2001. és 2011. évi népszámlálások elektronikus adatbázisa.

Korösszetétel

Az ország össznépességének folyamatos öregedésével szemben a németség korösszetétele 2001 és 2011 között valamelyest javult, de még mindig kedvezőtlen. A lemaradás továbbra is a gyermekkorúak arányában a legkifejezettebb az ország, és még inkább a Balmazújvárosi kistérség németsége esetében. Miközben az ország össznépességében a 0-14 évesek aránya 2001-ben 16,6\%-ot, 2011ben pedig 14,6\%-ot tett ki (tehát a gyermekek aránya csökkent), addig a németségben ez az arány 2001-ben 8,5\%, 2011-ben pedig 10,1\% volt, tehát a gyermekek aránya enyhén nőtt, de még mindig nem érte el az országos átlagot. A Balmazújvárosi kistérségben viszont, ahol 2001-ben még egyetlen német kötődésű 0-14 éves sem volt, a 2011. évi 7 fő a német kötődésűek 3,3\%-át tette ki.

Ugyanakkor a kistérségben az öregkorúak aránya is a 2001. évi 18,5\%-ról a 2011. évi 23\%-ra emelkedett. Egyedül a felnőtt korúak körében kedvező az elmozdulás a fiatalabb felnőtt korúak javára: a 15-39 évesek arányának 33,3\%-ról 36,4\%-ra való növekedését a 40-59 évesek 48,1\%-ról 37,3\%-ra való csökkenése ellentételezte. 
Gazdasági aktivitás

A Balmazújvárosi kistérség németségének gazdasági aktivitási mutatói igen kedvezőek: 2011-ben a 209 német kötődésü közül 110 volt foglalkoztatott (52,6\%), amivel a 150 kistérség sorában a 16. helyet foglalta el (9. táblázat). Ez az érték jelentősen meghaladta mind az össznépesség, mind a németség országos arányait.

9. táblázat: A Balmazújvárosi kistérség német kötődésü lakónépességének megoszlása gazdasági aktivitás szerint, 2011 (\%)

The distribution of people with German ties by activity status in the Balmazújváros Subregion, 2011 (\%)

\begin{tabular}{lcccc} 
& Foglalkoztatott & Munkanélküli & Inaktív kereső & Eltartott \\
\hline Népesség országosan, 2001 & 36,2 & 4,1 & 32,4 & 27,3 \\
Népesség országosan, 2011 & 39,7 & 5,7 & 29,7 & 24,9 \\
Németség országosan, 2001 & 40,2 & 2,6 & 38,2 & 19,1 \\
Németség országosan, 2011 & 44,3 & 4,2 & 30,9 & 20,6 \\
Németség a kistérségben, 2011 & 52,6 & 4,8 & 13,9 & 28,7
\end{tabular}

Forrás: KSH, 2001. és 2011. évi népszámlálások elektronikus adatbázisa.

Ha a korösszetételben mutatkozó különbségek semlegesítése érdekében megvizsgáljuk a 15-59 éves német kötődésűekre kiszámított gazdasági aktivitási arányokat, akkor ugyancsak azt állapíthatjuk meg, hogy 2011-ben az országos összlétszámukban összeírt 66,7\%-hoz képest a Balmazújvárosi kistérségben e korcsoport 70,8\%-a volt foglalkoztatott.

Végzettség

A Balmazújvárosi kistérség németségének jellemzői 2011-ben a végzettség tekintetében nem annyira kedvezőek, mint a gazdasági aktivitás tekintetében, de jobbak a németek országos átlagánál. A legnagyobb különbség a legalább középiskolával rendelkező német kötődésủek arányában mutatkozik: míg az országos összlétszámban 70,1\%, addig a Balmazújvárosi kistérség esetében 79,4\% az arányuk (10. táblázat). Az átlagosnál kedvezőbb arányokhoz legnagyobbrészt az érettségivel rendelkezők magas részesedése járult hozzá. 
10. táblázat: A Balmazújvárosi kistérség német kötődésü népességének végzettségi jellemzői, 2011 The education of people with German ties in the Balmazújváros Subregion, 2011

\begin{tabular}{lcccc}
\multirow{2}{*}{ Iskolai végzettség } & \multicolumn{2}{c}{ Németek országosan } & \multicolumn{2}{c}{ Németek a kistérségben } \\
\cline { 2 - 5 } & fő & $\%$ & fő & $\%$ \\
\hline Befejezett általános iskola nélkül & 23876 & 12,9 & 16 & 7,7 \\
Általános iskola 8 osztálya & 31668 & 17,1 & 27 & 12,9 \\
Középiskola érettségi nélkül & 29883 & 16,1 & 43 & 20,6 \\
Középiskola érettségivel & 54602 & 29,4 & 79 & 37,8 \\
Felsőfok & 45667 & 24,6 & 44 & 21,1 \\
Legalább középiskola & 130152 & 70,1 & 166 & 79,4 \\
Összesen & 185696 & 100 & 209 & 100
\end{tabular}

Forrás: KSH, 2001. és 2011. évi népszámlálások elektronikus adatbázisa.

A 20 éves és idősebb, legalább középiskolával rendelkező német kötődésủek aránya 2011-ben hasonlóképpen alakult: a német kötődésűek országos összlétszámában 81,2\%-ot, a Balmazújvárosi kistérség megfelelő korú németségében pedig $84 \%$-ot tett ki.

\section{A történelmi háttér}

Mint kimutattuk, a Balmazújvárosi kistérségben a születésük óta azonos lakcímen lakó német kötődésủek disszimilációból eredő 90\%-os minimális növekedési aránya kiemelkedően magas.

Ahhoz, hogy közelebb kerüljünk ennek magyarázatához, a társadalomszerkezeti tények mellett társadalomtörténeti szempontokat is figyelembe kell vennünk.

Balmazújvárosban a németség a 18. század közepén telepedett le, miután Mária Terézia 1753-ban Újváros (Balmazújváros korabeli neve) határát a császárhủ siklósi Andrássy Zsigmond özvegyének adományozta. A család a gazdálkodás fellendítése céljából a szabadalmas mezővárost robotra kötelezett jobbágyközséggé tette, ami az újvárosi jobbágyok ellenkezését váltotta ki (Katona 1997: 9). Ezt követően, 1766-ban az Andrássyak behívták a német telepeseket, s szerződésben biztosítottak nekik kedvező feltételeket a gazdálkodáshoz (Katona 1997: 32). 
A gazdasági eredmények nem maradtak el, ugyanakkor a német telepesek gyorsan beolvadtak a magyarságba. A magyar nyelvű istentiszteletek bevezetése mellett az 1880-as évek közepén a német mint tanitási nyelv is kezdett megszűnni, az anyakönyveket pedig 1883-tól magyarul vezették, még a német eredetủ neveket is magyar változatukban anyakönyvezték (Katona 1997: 39).

Ugyanez a folyamat tükröződött a népszámlálási adatokban is, különösen az után, hogy „Egy-egy falu lakosságát drasztikus módon ébresztették rá, hogy nem magyarok. Magyarul gondolkodtak, magyarul éreztek, a magyar kultúra részesei voltak. [...] A balmazújvárosiak nemzeti hovatartozandósága sem volt kétséges 1945-ig. Sok német nevűnek már az ükapja sem tudott németül." (Szebeni 1991: 9.)

11. táblázat: A Balmazújvárosi kistérség német anyanyelvü, illetve nemzetiségü népessége, 1880-2011 Population data for German native speakers and ethnic Germans in the Balmazújváros Subregion, 1880-2011

$\begin{array}{rrr}\text { Év } & \text { Anyanyelv } & \text { Nemzetiség } \\ 1880 & 1680 & \text { n. a. } \\ 1890 & 19 & \text { n. a. } \\ 1900 & 105 & \text { n. a. } \\ 1910 & 187 & \text { n. a. } \\ 1920 & 14 & \text { n. a. } \\ 1930 & 16 & \text { n. a. } \\ 1941 & 3 & 1 \\ 1949 & 1 & 0 \\ 1960 & 1 & 1 \\ 1980 & 5 & 5 \\ 1990 & 4 & 3 \\ 2001 & 8 & 13 \\ 2011 & 17 & 151\end{array}$

Forrás: KSH, 1880-2011 közötti népszámlálások.

1945. január 13-án összesen 547 személyt deportáltak a mai Balmazújváros településről a Szovjetunióba, 80\%-uk (430 fő) volt német származású.

Lehet, hogy Balmazújváros németségét - amint az idézet mondja - 1945-ben „drasztikus módon ébresztették rá” arra, hogy „nem magyarok”. Ébredésüknek azonban csak a rendszerváltás után adtak hangot nyilvánosan. 
Három okot is feltételezhetünk amögött, hogy feltámadt az itt megtelepedett őseik nemzetiségéhez való kötődésük.

Egyrészt az életkori jellegzetességükből eredő, személyes sorsuk megalapozására vonatkozó igényt, bár - mint más kistérségek példáiból is látható - a disszimiláció jelensége az időskorúak esetében is kimutatható. (A mintából eredő módszertani problémákat lásd $A z$ extrapolálás kockázatai címú részben.)

Második okként a rendszerváltás után megváltozott légkört feltételezhetjük, amelyben megindult a németség helyi önszerveződése, és nem utolsó sorban megalakult a német kisebbségi önkormányzat is.

Harmadsorban az is lehetséges, hogy 2011-ben a társadalmi-gazdasági válságban, biztos gyökerek után kutatva tartották fontosnak kinyilvánítani a németséghez való kötődésüket, amihez a német állam megerősödött tekintélye is hozzájárulhatott.

Ennyi minden lehet egyetlen statisztikai mutatószám mögött.

\section{Mohácsi kistérség: a regresszió példája}

A Baranya megyében található Mohácsi kistérség a 2001. évi népszámlálás adatai szerint a Budapesti kistérség után Magyarország második legnagyobb németek lakta kistérsége volt. 2011-re megelőzte a Pilisvörösvári kistérség, viszszaesett tehát a harmadik helyre, mert a német kötődésűek száma a 2001. évi 10641 főről 9418-ra csökkent. Miközben tehát 2001-ben a Magyarországon öszszeírt német kötődésűek 8,8\%-át adta, addig 2011-ben a részesedése már csak $5 \%$-ot tett ki.

Hasonló módon, de enyhébb mértékben fogyott a születésük óta azonos lakcímen lakók száma is. E kategóriában 2001-ben 2310 fővel meggyőzően foglalta el az első helyet, megelőzve nemcsak a Pilisvörösvári, hanem az akkor harmadik helyezett Budapesti kistérséget is, e kategória országos összlétszámának 11,9\%-ával. A 2011. évi 2133 fővel 6,4\%-ra apadt a részesedése, de a születésük óta azonos lakcímen lakók számának csökkenése jóval kisebb volt, mint a német kötődésűek összlétszámáé.

\section{A disszimilánsok számának minimuma}

Mindez visszatükröződik a disszimiláció mutatóiban is. A 2011. évi népszámláláskor szinte alig volt olyan évjárat, amelyben a lakóhelyén születettek körében több német kötődésűt írtak volna össze, mint 2001-ben. Ugyanakkor az 1973 és 
1983 között születettek körében tetemes a demográfiai veszteség (ők a 2011. évi népszámlálás időpontjában 28-38 évesek voltak, tehát a munkára foghatók legjobb életkorában).

Eközben 2011-ben a születése óta azonos lakcímen lakó 2133 német kötődésü között legkevesebb 116 olyan volt, aki 2001-ben ugyanott lakott, de akkor még nem mondta magát németnek. Ők a születésük óta azonos lakcímen lakó német kötődésűek 5,4\%-át képezték, de ez a 2001 és 2011 közötti születésekkel (395 fő, a 2011. évi létszám 18,5\%-a) együtt sem volt elegendő az elhalálozás, az elvándorlás és az asszimiláció együttes hatásából eredő 688 fős fogyás ellentételezésére. Másképpen fogalmazva: bár a születések száma több mint kétszeresen (225,2\%) meghaladta a 2001. és 2011. évi létszámkülönbség összegét, a halálozás, az elvándorlás és az asszimiláció okozta együttes veszteség a két népszámlálás közötti létszámcsökkenés több mint háromszorosa (323,2\%) volt (12. táblázat).

12. táblázat: A születésük óta azonos lakcímen lakó német kötődésüek 2001-2011 közötti disszimilációs növekményének minimuma a Mohácsi kistérségben

The minimal dissimilation increment (between 2001 and 2011) of people with German ties in the Mohács Subregion who have resided at the same place since birth

$\begin{array}{ccc}\begin{array}{c}\text { Különbözet, } \\ \text { fő }\end{array} & \text { A 2001-2011. évi } & \text { A 2011. évi } \\ \text { növekményből, \% } & \text { összlétszámból, \% }\end{array}$

$\begin{aligned} & \text { Fogyás sorok összege }= \\ & \text { a halálozás+elvándorlás+ } \\ & \text { asszimiláció minimuma }\end{aligned}$
$\begin{aligned} & \text { Többlet sorok összege }= \\ & \text { a disszimilánsok számának }\end{aligned}$
$\begin{aligned} & \text { minimuma } \\ & \text { Születések, 2001-2011 }\end{aligned}$
$\begin{aligned} & \text { 2011-2001 különbözet összesen } \\ & \text { Többlet és fogyás különbözete }\end{aligned}$

Forrás: KSH, 2001. és 2011. évi népszámlálások elektronikus adatbázisa. 


\section{A válaszkombinációk}

A német kötődésűek válaszkombinációinak részesedését összehasonlítva megfigyelhetjük, hogy a Mohácsi kistérségben azok száma csökkent a legnagyobb mértékben, akik anyanyelvük és családban beszélt nyelvük alapján vallották magukat a németséghez kötődőnek, nemzetiségükként viszont nem a németet jelölték meg (13. táblázat).

13. táblázat: A német kötődésüek válaszkombinációinak összehasonlitása, Mohácsi kistérség, 2001, 2011 Comparison of response combinations of people with German ties, Mohács Subregion, 2001, 2011

\begin{tabular}{lcccrrrrr}
$\begin{array}{l}\text { Válasz- } \\
\text { komb. }\end{array}$ & \multicolumn{3}{c}{ Identitáskategória } & \multicolumn{2}{c}{2001} & & 2011 & $2011 / 2001$ \\
\hline 01 & nemz & anye & csbeny & \multicolumn{1}{c}{ fő } & $\%$ & fő & $\%$ & $\%$ \\
03 & $X$ & - & - & 1682 & 18,3 & 3082 & 32,7 & 14,5 \\
04 & - & $X$ & - & 401 & 4,4 & 116 & 1,2 & $-3,1$ \\
07 & - & - & $X$ & 956 & 10,4 & 778 & 8,3 & $-2,1$ \\
08 & $X$ & $X$ & - & 820 & 8,9 & 682 & 7,2 & $-1,7$ \\
10 & $X$ & - & $X$ & 979 & 10,6 & 1471 & 15,6 & 5,0 \\
19 & $X$ & $X$ & $X$ & 3613 & 39,3 & 3132 & 33,3 & $-6,0$ \\
Összesen & - & $X$ & $X$ & 754 & 8,2 & 157 & 1,7 & $-6,5$ \\
Csak kulturális kötődés & & & & 9205 & 100 & 9418 & 100 & \\
Együtt & & & & 1436 & & & &
\end{tabular}

Forrás: KSH, 2001. és 2011. évi népszámlálások elektronikus adatbázisa.

Megjegyzés: Az X-szel jelölt identitáskategóriák azt jelölik, hogy az adott sorban összeszámolt személyek mely népszámlálási kérdések (nemzetiség; anyanyelv; családi, baráti közösségben beszélt nyelv) szerint mondták magukat a németséghez kötődőnek. Miután a 2011. évi népszámlálás - a 2001. évivel ellentétben - nem kérdezett rá a kulturális kötődésre, mindazok számát, akik 2001-ben kizárólag ennek kapcsán jelezték a németséghez való kötődésüket, külön sorban tüntettük fel, de értelemszerüen nem vontuk be az összehasonlításba.

\section{Az identitáskategóriák}

Az identitáskategóriák esetében is az anyanyelv hanyatlása a legnagyobb mértékű, miközben a magukat német nemzetiségünek vallók száma csekély mértékben még növekedett is (14. táblázat). 
14. táblázat: A német kötődésüek által jelölt identitáskategóriák, Mohácsi kistérség, 2001, 2011 Identity categories indicated by people with German ties, Mohács Subregion, 2001, 2011

\begin{tabular}{cccc} 
Év & Nemzetiség & Anyanyelv & Családi nyelv \\
2001 & 7094 & 5588 & 6302 \\
2011 & 8367 & 4087 & 5538 \\
\hline
\end{tabular}

Forrás: KSH, 2001. és 2011. évi népszámlálások elektronikus adatbázisa.

Korösszetétel

A Mohácsi kistérség németségének korösszetétele minden összehasonlításban kimondottan kedvezőtlen.

A kistérség németsége körében - az ország össznépességéhez és németségéhez viszonyítva is - kevesebb a gyermekkorú és a fiatalabb felnőtt korú személy. 2001-ben a 0-14 évesek aránya az ország össznépességében 16,6\%-ot, az ország németségében pedig 8,5\%-ot tett ki, ráadásul a Balmazújvárosi kistérségben a 9\%-os arány még valamelyest meg is haladta az ország össznémetségének körében jegyzett értéket. 2011-re viszont, miközben az ország németségének körében a 0-14 évesek aránya 10,1\%-ra emelkedett, addig a Mohácsi kistérségben a gyermekkorúak aránya tovább csökkent (8,9\%), akárcsak a fiatalabb felnőtt korúaké (a 2001. évi 26,3\%-ról a 2011. évi 25\%-ra). Az ellentételezés nagyjából egyenletesen oszlott meg a két idősebb korcsoport között.

\section{Gazdasági aktivitás}

A Mohácsi kistérség németségének gazdasági aktivitási mutatói jelentősen alulmúlják nemcsak az ország németségének, hanem össznépességének mutatóit is (15. táblázat).

A foglalkoztatottak 39,1\%-os részesedése a Balmazújvárosi kistérséggel (52,6\%) összehasonlítva rendkívül alacsony, s az eltérést nem a munkanélküliek (4,8\% : 4,3\%), hanem részben az inaktív keresők (13,9\% : 16,1\%), de még inkább az eltartottak (28,7\% : 40,5\%) rendkívül magas aránya ellentételezi, amit a gyerek- 
korúak részesedése semmiképpen nem indokol. Ez utóbbi körülmény tisztázása külön vizsgálatot igényel.

15. táblázat: A Mohácsi kistérség német kötődésü lakónépességének megoszlása gazdasági aktivitás szerint, 2011

Activity status of people with German ties residing in the Mohács Subregion, 2011

\begin{tabular}{lcccc} 
& Foglalkoztatott & Munkanélküli & Inaktív kereső & Eltartott \\
\hline Népesség országosan, 2001 & 36,2 & 4,1 & 32,4 & 27,3 \\
Népesség országosan, 2011 & 39,7 & 5,7 & 29,7 & 24,9 \\
Németség országosan, 2001 & 40,2 & 2,6 & 38,2 & 19,1 \\
Németség országosan, 2011 & 44,3 & 4,2 & 30,9 & 20,6 \\
Németség a kistérségben, 2011 & 39,1 & 4,3 & 16,1 & 40,5
\end{tabular}

Forrás: KSH, 2001. és 2011. évi népszámlálások elektronikus adatbázisa.

A korösszetételben mutatkozó különbségek semlegesítése érdekében a 1559 éves német kötődésűekre kiszámított gazdasági aktivitási arányok azt mutatják, hogy míg 2011-ben a Mohácsi kistérségben a német kötődésűek körében a foglalkoztatottak aránya (66,8\%) szinte teljesen megegyezik az ország németségét jellemző aránnyal (66,7\%), addig ez az arány a Balmazújvárosi kistérség németségének körében jóval magasabb (70,8\%).

\section{Végzettség}

A Mohácsi kistérség németségének végzettségi mutatói az ország németségéhez viszonyítva kedvezőtlenek: sok a befejezett általános iskola nélküli, kevés a felsőfokú végzettségü (16. táblázat).

Még nagyobb az eltérés a Balmazújvárosi és a Mohácsi kistérség németségének végzettségi mutatói között: a Mohácsi kistérségben kétszer akkora a befejezett általános iskola nélküliek aránya, és a felsőfokú végzettségűek aránya is alig haladja meg a Balmazújvárosi kistérségbeli felét. Míg 2011-ben a Balmazújvárosi kistérség németségének 79,4\%-a rendelkezett legalább középiskolával, addig a Mohácsi kistérségbeli németek mindössze 58,3\%-a. 
16. táblázat: A Mohácsi kistérség német kötődésü népességének végzettségi jellemzői, 2011 The education of people with German ties residing in the Mohács Subregion, 2011

\begin{tabular}{lcccc}
\multirow{2}{*}{ Iskolai végzettség } & \multicolumn{2}{c}{ Németek országosan } & \multicolumn{2}{c}{ Németek a kistérségben } \\
\cline { 2 - 5 } & fő & $\%$ & fő & $\%$ \\
\hline Befejezett általános iskola nélkül & 23876 & 12,9 & 1479 & 15,7 \\
Általános iskola 8 osztálya & 31668 & 17,1 & 2445 & 26,0 \\
Középiskola érettségi nélkül & 29883 & 16,1 & 2075 & 22,0 \\
Középiskola érettségivel & 54602 & 29,4 & 2310 & 24,5 \\
Felsőfok & 45667 & 24,6 & 1109 & 11,8 \\
Legalább középiskola & 130152 & 70,1 & 5494 & 58,3 \\
Összesen & 185696 & 100 & 9418 & 100
\end{tabular}

Forrás: KSH, 2001. és 2011. évi népszámlálások elektronikus adatbázisa.

Ugyanígy, miközben a 20 éves és idősebb, legalább középiskolával rendelkező német kötődésűek aránya 2011-ben a német kötődésűek országos összlétszámában 81,2\%-ot, a Balmazújvárosi kistérség megfelelő korú németségében pedig 84\%-ot tett ki, addig a Mohácsi kistérségben ez az arány mindössze $65,8 \%$.

\section{A történelmi háttér}

A Mohácsi kistérség területére való betelepítések az 1600-as évek végén kezdődtek. A szerbek és horvátok mellett a Rajna mentéről, Fulda környékéről, Frankföldről hajón vagy tutajon érkező német telepesek nagy része Mohácson kötött ki, és innen mentek tovább az uradalmakba.

2001-ben a Mohácsi kistérség 47 települése közül csak egyben (Kékesben) nem írtak össze egyetlen német kötődésű személyt sem. Kétharmaduk (66,2\%) azonban 9 településen élt, így az áttekinthetőség kedvéért ezek népszámlálási adatsoraival mutatjuk be a Mohácsi kistérségben a németség létszámának alakulását, szemléltetve egyúttal azt is, hogy a kistérségi mutatószámok milyen mértékben fedik el a részletek eltéréseit (17. táblázat).

Arányokban kifejezve: az egyes települések 1880-ban 100 indexponttal jelzett német anyanyelvű népessége 1941-ig annak 104-160\%-ára nőtt, majd a második világháború utáni üldöztetés, kényszermunka és kitelepítések 
következtében 1949-re 0,7-22\%-ára apadt. Kisebb-nagyobb hullámzások után - amelyek részben a politikai hangulat, részben a szintén azzal összefüggő népszámlálási módszertan változásaiból eredtek - 2011-re az 1880. évi értékek 6-32\%-át érte el.

17. táblázat: A német anyanyelvü népesség létszám-változásának arányai a Mohácsi kistérség legnagyobb számban németek lakta településein (fó)

Changes in the population of German native-speakers in settlements inhabited by the greatest number of Germans in the Mohács Subregion (persons)

\begin{tabular}{rrrrrrrrrr} 
Év & Bóly & $\begin{array}{c}\text { Geresd- } \\
\text { lak }\end{array}$ & $\begin{array}{c}\text { Himes- } \\
\text { háza }\end{array}$ & $\begin{array}{l}\text { Lány- } \\
\text { csók }\end{array}$ & Mohács & $\begin{array}{r}\text { Palota- } \\
\text { bozsok }\end{array}$ & $\begin{array}{r}\text { Som- } \\
\text { berek }\end{array}$ & $\begin{array}{r}\text { Szeder- } \\
\text { kény }\end{array}$ & Véménd \\
\hline 1880 & 2211 & 2470 & 1337 & 1279 & 1638 & 1426 & 1311 & 996 & 1565 \\
1890 & 2748 & 3044 & 1573 & 1523 & 2173 & 1570 & 1561 & 1237 & 1870 \\
1900 & 2517 & 2948 & 1637 & 1483 & 1999 & 1569 & 1372 & 1178 & 1882 \\
1910 & 2698 & 3202 & 1522 & 1490 & 2081 & 1709 & 1465 & 1314 & 1816 \\
1920 & 2518 & 3222 & 1562 & 1693 & 2159 & 1705 & 1396 & 1440 & 1804 \\
1930 & 2078 & 3194 & 1616 & 1701 & 1920 & 1497 & 1613 & 1504 & 2130 \\
1941 & 2290 & 3206 & 1529 & 1847 & 2026 & 1648 & 1738 & 1591 & 2280 \\
1949 & 16 & 472 & 90 & 217 & 362 & 76 & 265 & 81 & 63 \\
1960 & 131 & 1474 & 769 & 421 & 902 & 292 & 644 & 469 & 203 \\
1980 & 53 & 417 & 620 & 295 & 588 & 278 & 612 & 330 & 310 \\
1990 & 173 & 421 & 577 & 280 & 975 & 408 & 744 & 417 & 459 \\
2001 & 268 & 283 & 571 & 252 & 736 & 368 & 519 & 329 & 363 \\
2011 & 201 & 158 & 338 & 138 & 529 & 130 & 317 & 231 & 245
\end{tabular}

Forrás: KSH, 1880-2011 közötti népszámlálások.

Magyarországon a népszámlálás először 1941-ben kérdezett rá az anyanyelv mellett a nemzetiségre is, mint aktív és szubjektív identitáskategóriára (18. táblázat).

Ha az 1941. évi értéket 100 indexpontnak vesszük, akkor látjuk, hogy 1949ben Mohácson ez az érték éppen csak elérte az 1\%-ot, a többi vizsgált településen pedig 0,1-0,3\% között volt. 2011-re viszont Mohácson a magukat német nemzetiségüeknek vallók száma az 1941. évi érték 138,6\%-át tette ki.

Bár a kistérség többi településén a németet nemzetiségüknek vallók száma a 2001. évi értékhez képest csökkent, a kistérség egészét tekintve, még így is sze- 
rény növekedést mutat (117,9\%). Ez azonban jelentősen elmarad a német nemzetiségűek létszám-növekedésének országos mértékétől (212,5\%).

18. táblázat: A német nemzetiségü népesség létszám-változásának arányai a Mohácsi kistérség legnagyobb számban németek lakta településein (fö)

Changes in the population of ethnic Germans in settlements inhabited by the greatest number of Germans in the Mohács Subregion (persons)

$\begin{array}{rrrrrrrrrr}\text { Év } & \text { Bóly } & \begin{array}{c}\text { Geresd- } \\ \text { lak }\end{array} & \begin{array}{c}\text { Himes- } \\ \text { háza }\end{array} & \begin{array}{c}\text { Lány- } \\ \text { csók }\end{array} & \text { Mohács } & \begin{array}{c}\text { Palota- } \\ \text { bozsok }\end{array} & \begin{array}{c}\text { Som- } \\ \text { berek }\end{array} & \begin{array}{c}\text { Szeder- } \\ \text { kény }\end{array} & \text { Véménd } \\ 1941 & 851 & 2750 & 1487 & 1638 & 1054 & 1503 & 1322 & 1166 & 1784 \\ 1949 & 1 & 8 & 2 & 3 & 11 & 2 & 1 & 1 & \text { n. a. } \\ 1960 & 27 & 34 & 17 & 19 & 78 & 83 & 18 & 4 & 27 \\ 1980 & 9 & 65 & 85 & 154 & 148 & 132 & 98 & 83 & 85 \\ 1990 & 208 & 217 & 578 & 211 & 831 & 295 & 412 & 294 & 344 \\ 2001 & 647 & 303 & 520 & 394 & 1238 & 376 & 463 & 460 & 376 \\ 2011 & 767 & 279 & 453 & 351 & 1461 & 249 & 482 & 482 & 346\end{array}$

Forrás: KSH, 1941-2011 közötti népszámlálások.

Ferkov Jakab, a nemzetiségi bázisintézményként működő mohácsi Kanizsai Dorottya Múzeum igazgatója írja tanulmányában: „Az egységes kultúra létrejöttét eredményező folyamatban kimutatható a kisebbségek egyre nagyobb eltávolodása az anyanemzet kultúrájától és a teljes beolvadáshoz vezető út minden fontos állomása. A kisebbségek léte a többségi nemzetbe való beolvadás előtt egyfajta köztes lét." (Ferkov 2015: 142.) A szerző - általunk borúlátónak tartott - megállapításával szemben a kistérségek összehasonlító elemzése alapján arra következtetünk, hogy a németség esetében a regressziv tendenciák a Mohácsi kistérségben is visszafordíthatók. Azt is feltételezzük, hogy a tapasztalatok más kisebbségek számára is hasznosithatók.

\section{ÖSSZEFOGLALÁS}

Ha a kistérségeket aszerint kivánjuk kategorizálni, hogy a születésük óta azonos lakcímen lakó német kötődésűek disszimilációs jellemzői a területükön hogyan járultak hozzá a német kötődésủek reprodukciójához, akkor három kategóriába sorolhatjuk őket. 
Az első kategóriába azok tartoznak, amelyek esetében a disszimilációs növekmény már önmagában is ellentételezi az asszimiláció, az elhalálozás és az elvándorlás együttes hatásából eredő fogyást. Ez a 150 kistérség közül 135-re érvényes. Ezekben a kistérségekben a német kötődésűek országos összlétszámának 83,9\%-a, a születésük óta azonos lakcímen lakók 80,5\%-a és a disszimilánsok 92,8\%-a élt.

A második kategóriába sorolt kistérségek esetében a disszimilációs növekmény nem volt elegendő a fogyás ellentételezésére, de a születések számának köszönhetően 2011-ben még mindig több volt a születésük óta azonos lakcímen lakók száma, mint 2001-ben. E kritérium alapján a következő 11 kistérség tartozik ide (zárójelben a disszimiláció minimális mértéke a 2011. évi összlétszámból): Tabi (59,4\%), Gárdonyi (53,8\%), Sátoraljaújhelyi (41,3\%), Sarkadi (40\%), Tatai (23,5\%), Oroszlányi (23,4\%), Rétsági (17,7\%), Tatabányai (14,5\%), Bajai (12,8\%), Dorogi (12,5\%), Dabasi (8,2\%). Ezekben a kistérségekben a német kötődésüek 8,8\%-át és a születésük óta azonos lakcímen lakók 10,4\%-át írták össze, illetve itt élt a disszimilánsok 5,2\%-a.

A harmadik kategóriába soroltuk azokat a kistérségeket, amelyek esetében a fogyás olyan mértékben haladta meg a disszimilációs növekményt, hogy utóbbi még a születések számával együtt sem tudta ellentételezni a különbséget. E kategóriába 4 kistérség tartozik: Szobi (25,4\%), Tamási (10,9\%), Pécsváradi (6,6\%), Mohácsi (5,4\%). Ezekre esik a német kötődésüek 7,4\%-a, a születésük óta azonos lakcímen lakók 9,1\%-a és a disszimilánsok 1,9\%-a.

Az ismertetett adatokat két szempontból célszerủ elemezni.

Egyrészt, meg kell vizsgálni, hogy a disszimilációs jellemzők területi különbségei milyen korrelációban állnak az adott kistérség demográfiai, gazdasági, politikai és kulturális sajátosságaival (külső tényezők), illetve magának a német közösségnek a helyi sajátosságaival (belső tényezők). Másrészt, támpontokat kell szerezni annak megítéléséhez, hogy a születésük óta azonos lakcímen lakók csoportjának jellemzői miben térnek el a német kötődésűek csoportja egészének jellemzőitől. Arra keresünk tehát választ, hogy kutatásunk alapján milyen megkötésekkel vonhatunk le a disszimiláció természetével kapcsolatos következtetéseket a magyarországi németség egészére nézve.

Ha a születésük óta azonos lakcímen lakó német kötődésủek 2011. évi összlétszáma disszimilációból eredő minimális mértékének kistérségi adatait összehasonlítjuk az említett tényezők mutatóival, a további kutatások kiindulópontjaként a következő hipotéziseket fogalmazhatjuk meg.

1. A disszimilációs jellemző nem áll szoros korrelációban sem a kistérség komplex fejlettségi mutatójával, sem annak komponenseivel. 
2. A disszimiláció minimális mértéke erős negatív korrelációban $(r=$ -0,59) áll a németségnek a kistérség össznépességében 2001-ben betöltött arányával. Vagyis: a legnagyobb arányban német kötődésủek által lakott kistérségekben a legkisebbek a disszimilációs minimumok értékei. Viszont ezt nem befolyásolhatja az élethosszig számított vándorlási arány, mert az egyes kistérségekben született és az azokban lakó német kötődésủek aránya, illetve a németségnek az össznépességben betöltött aránya között nincs szignifikáns korreláció, tehát nem a vándorlási különbözet rontja le a disszimiláció reprodukciós hatását.

3. A gazdasági aktivitási kategóriák aránya és a disszimilációs mutatók közötti kistérségenkénti korreláció minden vonatkozásban gyenge (tehát 0,5 alatti), akár a német kötődésűek kistérségenkénti összlétszámát, akár a 15-59 évesekét (a zárójelben feltüntetett értékeket) vizsgáljuk: foglalkoztatott $0,23(-0,23)$; munkanélküli 0,42 (0,33); inaktív kereső -0,09 $(0,28)$; eltartott -0,24 $(-0,16)$.

4. Ugyanígy nem tekinthető erősnek a német kötődésüek iskolai végzettsége és a születésük óta azonos lakcímen lakó német kötődésủek disszimilációs jellemzői közötti korreláció sem. (Befejezett általános iskola nélkül: -0,61; az általános iskola 8 osztálya: -0,11; középiskola érettségi nélkül: 0,24; középiskola érettségivel: 0,29; felsőfok: 0,14.) Valamivel erősebb volt a korreláció a legalább középiskolát végzettek tekintetében: 0,46.

Távol áll tölünk, hogy az ilyen lineáris összefüggések után szimatolva további átfogó elemzések nélkül mélyebb következtetéseket igyekezzünk levonni. A korrelációs koefficiensek ismertetésével éppen azt fejtegettük, hogy a disszimilációs jellemző, mint a nemzeti-etnikai identitás egyik megnyilvánulási formája, a területi mutatók egyikével sem áll erős korrelációban. Tehát az oksági összefüggések feltárásához mélyfúrások kellenek. Jelen tanulmány csak a mélyfúrások helyszínének kijelölésére szolgál.

Ezek a vizsgálatok azonban arra mindenképpen jók, hogy fölhívják a figyelmet: a disszimiláció jelenségének jobb megértésével, a tényezők viszonyrendszerének a társadalmi integrációs/dezintegrációs spirál mentén való elemezésével, a német közösségben zajló belső folyamatok vizsgálatával közelebb juthatunk a magyarországi társadalom egészének jobb megismeréséhez is. 


\section{AZ EXTRAPOLÁLÁS KOCKÁZATAI}

Ha a Balmazújvárosi kistérségben megvizsgáljuk az összes német kötődésü személy születési év szerinti megoszlását is, azt látjuk, hogy 2011-ben nemcsak azokban az évjáratokban van növekedés, amelyekben azt a születésük óta azonos lakcímen lakók esetében kimutattuk a disszimiláció minimális mértékeként, hanem szinte minden évjáratban. Még azoknál az idős korcsoportoknál is, amelyek esetében a halandóság magas arányát más kistérségekben már nem tudja ellentételezni a disszimiláció, és amelyek esetében szintén nem a bevándorlás magas arányát, hanem a disszimilációt kell feltételezni.

A Mohácsi kistérségben is hasonló arányokat állapíthatunk meg a német kötődésűek összlétszáma és azon belül a születésük óta azonos lakcímen lakók száma között, egy eltérésre azonban fel kell figyelnünk. A születésük óta azonos lakcímen lakók számában a 2001. évihez képest 2011-ben jelentős csökkenés áltt be az 1972 és 1984 között születettek (a 2011-ben 26-39 évesek) körében. Ezt a legaktívabb korúak elvándorlásával magyarázhatnánk, ami egybevág a kistérség kedvezőtlen gazdasági folyamataival. A német kötődésủek összlétszámában viszont ezen évjáratokban nem mutatkozik hiány, mintha azt éppen az odavándorlás ellentételezte volna, ami ellentmond mind a demográfiai, mind a gazdasági mutatóknak.

Az összes kistérségre vonatkozóan elmondhatjuk: 2001-ben a Sárospataki kistérségben volt a legmagasabb a német kötődésűek körében a születésük óta azonos lakcímen lakók aránya (498 főből 183, vagyis 36,7\%). 2011-re e kistérség a 4. helyre szorult vissza (629-ből 223 fő, 35,5\%). Tehát a két népszámlálás között, ha az országos átlag mértéke alatt is, de nőtt mind a német kötődésüek összlétszáma (126,3\%), mind pedig ezen belül az azonos lakcímen lakók száma (121,9\%). Az Aszódi kistérségben viszont ez a növekedés mindkét vonatkozásban sokkal nagyobb mértékủ volt (a német kötődésủek összlétszáma 2011-ben a 2001. évi 270,8\%-át, a születésük óta azonos lakcímen lakókénak a 380\%-át tette ki), így ez került az élre. A 150 kistérség közül mindössze egy olyan volt (a Dorogi), amelyben a két népszámlálás között a német kötődésủek, illetve ezen belül a születésük óta azonos lakcímen lakók száma sem nőtt, illetve csökkent párhuzamosan (a korreláció: 0,78).

Mindez arra ösztönöz bennünket, hogy tovább kutassunk az olyan módszertani megoldások után, amelyek a disszimiláció mérését szélesebb körben is lehetővé teszik. 


\section{IRODALOM}

Ferkov Jakab 2015: A nemzetiségek kultúraátadási sajátosságai Mohács példáján. Forrás, 47(7-8), 142-159.

Kapitány Balázs 2013: Kárpát-medencei népszámlálási körkép. Demográfia, 56(1), 25-64. Kapitány Balázs 2015: A magyarországi történelmi kisebbségi közösségek demográfiai viszonyai és perspektívái 1900-2011 között. Kisebbségkutatás, 24(3), 69-101.

Katona Mária 1997: Két évszázada Balmazújvároson - a balmazújvárosi németek története. Balmazújvárosi Múzeum, Balmazújváros.

Morauszki András - Papp Z. Attila 2014: Nemzetiségi revival? Magyarország nemzetiségei a 2011. évi népszámlálás megváltozott módszertana tükrében. Kisebbségkutatás, 23(3), 73-98.

Pongrácz Tiborné 2013: A Ratkó-korszak. Korfa, 13(1), 1-4.

Szebeni Ilona 1991: Merre van a magyar hazám? Széphalom Könyvmühely, Debrecen.

Tóth Ágnes - Vékás János 2008: A népszámlálások nemzeti-etnikai adatai mögött rejlő politikai tényezők (1949-1990). Kisebbségkutatás, 17(3), 406-431.

Tóth Ágnes - Vékás János 2013: A magyarországi nemzetiségek létszámváltozása 2001 és 2011 között. Statisztikai Szem/e, 91(12), 1256-1267.

Tóth, Ágnes - Vékás, János 2014a: National and Ethnic Minorities in Hungary in the Period 2001-2011. Ethno-Demographic Trends as Reflected in the Census Data. Hungarian Statistical Review, 92(17), 95-112.

Tóth Ágnes - Vékás János 2014b: Nemzetiségek Magyarországon 2001-2011. Etnodemográfiai folyamatok a népszámlálások tükrében. Kisebbségkutatás, 23(3), 36-72.

Tóth, Ágnes - Vékás, János 2016: Minderheit und Mehrheit. Divergente etnodemographische Prozesse zwischen 2001 und 2011. In Radek, Tünde - Szilágyi-Kósa, Anikó (Hrsg.): Wandel durch Migration. Komitatsarchiv Veszprém des Ungarischen Nationalarchivs, Veszprém, 133-155. 


\section{REGIONAL FEATURES OF DISSIMILATION IN THE ETHNIC GERMAN COMMUNITY IN HUNGARY}

\section{ABSTRACT}

Subregional data from the Hungarian censuses of 2001 and 2011 were used to calculate the minimal effect of dissimilation on increases in the population of people with ties to the German national minority.

For the purposes of the analysis, people with German ties were defined as those who opted for "German" in response to at least one census question pertaining to national and ethnic affiliation.

Dissimilants were those who identified themselves as people with German ties at the time of the 2011 census but who had not declared an affiliation to the German community in response to any of the census questions in 2001.

With a view to eliminating the effects of migration, the analysis was limited to those people with German ties who had resided at the same place since birth, and it compared the number of people in the various year-of-birth cohorts.

The analysis concluded that there is a wide variance in the minimal dissimilation index at the subregional level but it has no close correlation with the basic indicators for the subregions or for the people with German ties who inhabit them. Based on the dissimilation indicators elaborated during the analysis, it would seem sensible to designate those areas where further detailed research on social structure and social history may reveal the causal factors pertaining to dissimilation. 